\title{
日本フェロアロイ工業の構造改善と技術的発達についで
}

\author{
那須 重 治**

\section{Some Aspects of Structural Improvements and Technical Progresses in Japanese Ferroalloy Industry}

Juji NASU

\section{1. まえがき}

日本におけるフェロアロイの生産は, 明治 33 年(1900 年）に金石におけるフェロマンガンおよびスピーゲル の生産に始まつた. これは公称能力 10 トンの高炉生産 である．電気炬による生産は，釜石におくれること 14 年後の大正 3 年(1914年) に八幡製鉄所において製造試 験に着手したのが始まりであり, その後余剩電力, 余剩 労働力を求めて東北, 北陸地方で数多くの電気炉がわが 国のフェロアロイの生産を行なつてきた.

その後昭和 18 年の生産量 17 万 3000 トンを頂点と して昭和 20 年には戦災と終戦により激減したが, 昭和 23 からやつと再生産に入り 2 万 8000 トン生産し, 昭 和 30 年には 21 万 4000 トンとなり, その後は日本の 鉄鋼生産の伸びとともに発展し現在にいたつている.

以下に, 日本フェロアロイ工業に発展をもたらした要 因の一つである構造改善と技術的発達について述べる.

\section{2. 生産の推移と構造改善}

\section{$2 \cdot 1$ 合理化対策}

昭和 38 年度以降鉄鋼生産の急激な伸びにともない, フェロアロイ供給体制も従来の余剩電力による生産から 安定した供給を要望され, 生産体制を逐次その方向に向 う必要が痛感された. 最盛期には 60 上を越える各企業 による多品種少量生産の業態は, 需要家に対して諸種の 問題点を残していた．このため抜本的对策を樹立する必 要が痛感され, 日本フェロアロイ協会に企業合理化対策 委員会が設置され, 通産省の指導のもとで体制整啃, 合 理化対策などについて業界将来の方向付けが行なわれ， 昭和 38 年 11 月に成案を得て昭和 39 年 1 月「フェロ アロイ工業合理化対策」1) の完成を見た．以来これがわ が国フェロアロイ工業合理化の基本满想となついてい る.

この基本方針は次のとおりである.

（1）国産品による安定した供給をはかる.

（2）体制整備の方向としては，企業の自立体浏をは かるとともに, 企業間の提携, 共同投資, 合併な
どの企業のグループ化を進め，生産品種の分野調 整，集中生産による合理化をはかる.

（3）流通機懳の整備を行ない，販売面での過当競争 を避ける。

（4）技術の合理化のための共同研究を進め改善をは かる.

（5）原料入手対策として，共同贈入体制の推進，海 外鉱山の共同開発を進める.

（6）電力の安定確保をはかる.

（7）モデルプラントの立案を行ない，将来の企業統 合あるいはグループ化が促進されたときに，これ によつて適地に大規模新鋭工場を設置する．この ための設備内容，コストの算定を行ない，わが国 フェロアロイ工業発展の可能性を莙える参考とす る.

\section{$2 \cdot 2$ 生産量の推移}

罒 1 に示すように，鉄鋼の生産にともなつてフェロア ロイの生産も急激に伸びている，昭和 30 年度には粗鋼 980 万トン，フェロアロイ 21 万トンであつたが，昭和 40 年度には粗鋼 4100 万トン,フェロアロイ 66 万トン となり，さらに昭和 47 年には粗鋼 9700 万トンで 1 億トンになるのも眼前であり，同様にフェロアロイも 199 万トンで 200 万トンに近づいている. 昭和 30 年と 比較して両者共に約 10 倍になつている.

一方，世界のフェロアロイのすう勢を見ると，図 2 お よび表 2 に示すように，共産圏を除きアメリカが第 1 位 で 1965 年約 255 万トンを最高として次第に減少し 1971 年には約 240 万トンになつた. 日本は第 2 位，， ルウェーは約 76 万トンで第 3 位, 西ドイッは約 50 万 トンでほぼ横ばいで，一方南アフリカ共和国は次第に増 加し約 43 万トンに達し最近新鋭炉が続々と建設されて おり今後はかなりの生産量が見込まれている.

表 1 に昭和 41 年より昭和 47 年までの品種別フェ口 アロイ生産の推移を示し, 図 3 に昭和 47 年のフェロア

* 昭和 48 年 4 月本会非演大会にて発表 昭和48年 5 月 2 日受付

** 䅇村金属工業(株)工博 


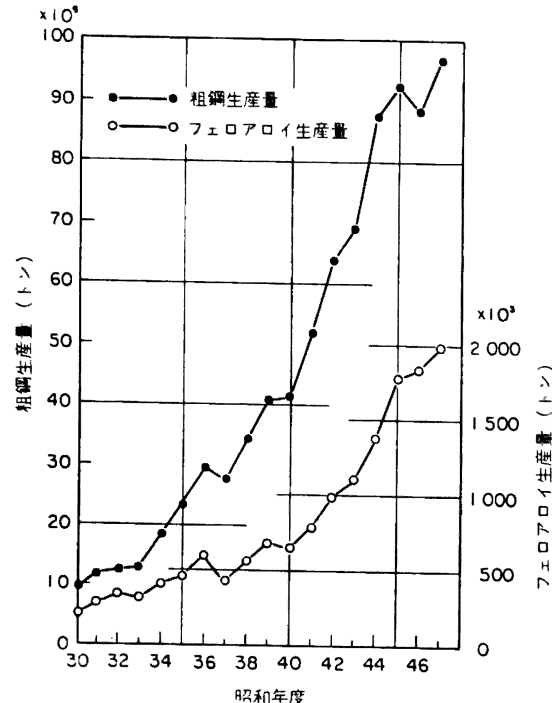

図1フェロ丁ロイ生産量推移（鉄鋼統計）

ロイ生産品種を円グラフで示す. 主要品種はフェロマン ガン, シリコマンガン, フェロクロム, フェロシリコン およびフェロニッケルで，とくにマンガン系は $54 \%$ を

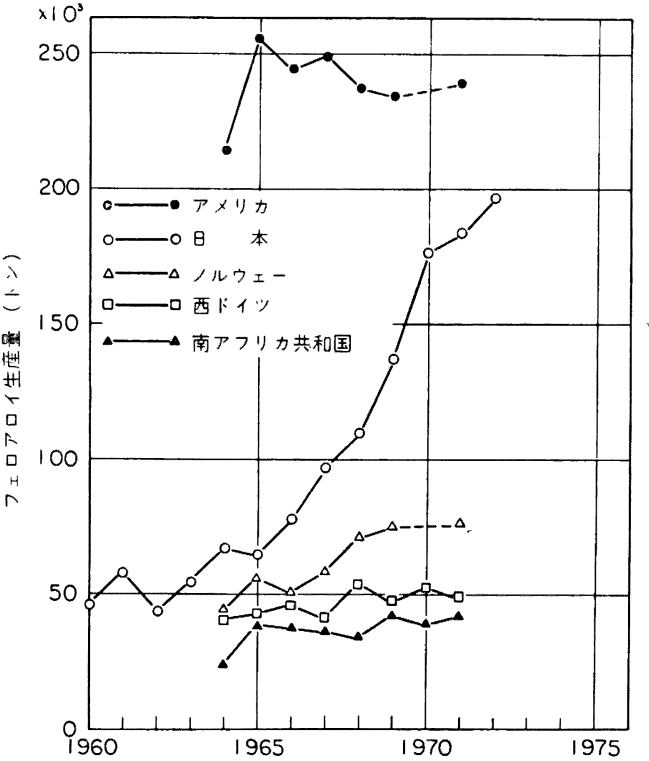

四 2 世界各国のフェロフロイ生産量の推移

(Metal Bulletin Handbook, その他より) 占めている.

表 1 品種別フェロ丁ロイ生産の推移（単位トン）

(日本フェロフロイ協会資料)

\begin{tabular}{|c|c|c|c|c|c|c|c|c|}
\hline & & & & & & & \multicolumn{2}{|c|}{47 年 } \\
\hline 吅 & & & & & & & $ト \quad ン$ & $\%$ \\
\hline 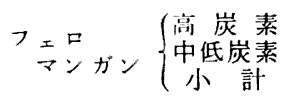 & $\begin{array}{r}202673 \\
50344 \\
253017\end{array}$ & $\begin{array}{r}265115 \\
52572 \\
317687\end{array}$ & $\begin{array}{r}287827 \\
68848 \\
356675\end{array}$ & $\begin{array}{r}323921 \\
70290 \\
394211\end{array}$ & $\begin{array}{r}389915 \\
87418 \\
477333\end{array}$ & $\begin{array}{r}447258 \\
93596 \\
540854\end{array}$ & $\begin{array}{l}482670 \\
124194 \\
606864\end{array}$ & $\begin{array}{c}24 \cdot 27 \\
6 \cdot 25 \\
(30 \cdot 52)\end{array}$ \\
\hline 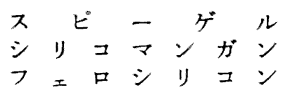 & $\begin{array}{r}589 \\
137088 \\
141329\end{array}$ & $\begin{array}{r}718 \\
184138 \\
149672\end{array}$ & $\begin{array}{r}392 \\
191831 \\
178266\end{array}$ & $\begin{array}{r}129 \\
244724 \\
243715\end{array}$ & $\begin{array}{r}737 \\
283886 \\
318764\end{array}$ & $\begin{array}{r}-\overline{-} \\
323924 \\
313789\end{array}$ & $\begin{array}{r}- \\
467828 \\
292405\end{array}$ & $\begin{array}{l}-\overline{-} \\
23 \cdot 53 \\
14 \cdot 71\end{array}$ \\
\hline$フ_{\text {フ }}$ クロ $\begin{array}{c}\text { 高中炭素 } \\
\text { 低炭素 } \\
\text { 小計 }\end{array}$ & $\begin{array}{r}92365 \\
62805 \\
155170\end{array}$ & $\begin{array}{r}128886 \\
73374 \\
202260\end{array}$ & $\begin{array}{r}151798 \\
68518 \\
220316\end{array}$ & $\begin{array}{r}185686 \\
88069 \\
273755\end{array}$ & $\begin{array}{l}271524 \\
117247 \\
388771\end{array}$ & $\begin{array}{l}248445 \\
120539 \\
368984\end{array}$ & $\begin{array}{r}247742 \\
71315 \\
319057\end{array}$ & $\begin{array}{c}12 \cdot 46 \\
3 \cdot 59 \\
(16 \cdot 05)\end{array}$ \\
\hline 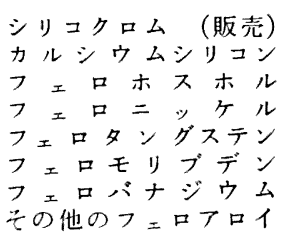 & $\begin{array}{r}24079 \\
7999 \\
2410 \\
82159 \\
790 \\
1840 \\
1557 \\
420\end{array}$ & $\begin{array}{r}31377 \\
8327 \\
2329 \\
111754 \\
1066 \\
2103 \\
1480 \\
771\end{array}$ & $\begin{array}{r}37044 \\
10100 \\
2427 \\
139656 \\
776 \\
2306 \\
1668 \\
666\end{array}$ & $\begin{array}{r}50914 \\
10834 \\
2243 \\
202175 \\
1337 \\
2655 \\
2320 \\
811\end{array}$ & $\begin{array}{r}37943 \\
12671 \\
2462 \\
285343 \\
1152 \\
3006 \\
2522 \\
558\end{array}$ & $\begin{array}{r}32566 \\
9089 \\
2616 \\
260541 \\
644 \\
2322 \\
2272 \\
963\end{array}$ & $\begin{array}{r}26805 \\
9361 \\
1736 \\
202200 \\
609 \\
2234 \\
2450\end{array}$ & $\begin{array}{r}1 \cdot 35 \\
0 \cdot 47 \\
0 \cdot 09 \\
10 \cdot 17 \\
0 \cdot 03 \\
0 \cdot 11 \\
0 \cdot 12\end{array}$ \\
\hline 計 & 808447 & 1013682 & 1142123 & 1429823 & 1815143 & 1858564 & 1931549 & $(97 \cdot 15)$ \\
\hline $\begin{array}{ccc}\text { 金属 } & \text { 属げ } \\
\text { 素 }\end{array}$ & $\begin{array}{r}4808 \\
18755\end{array}$ & $\begin{array}{r}6539 \\
19919\end{array}$ & $\begin{array}{r}7041 \\
25284\end{array}$ & $\begin{array}{r}7641 \\
26795\end{array}$ & $\begin{array}{l}10212 \\
35416\end{array}$ & $\begin{array}{ll}14 & 154 \\
44 & 155\end{array}$ & $\begin{array}{l}12612 \\
44203\end{array}$ & $\begin{array}{l}0 \cdot 63 \\
2 \cdot 22\end{array}$ \\
\hline 計 & 832010 & 1040140 & 1174448 & 1464259 & 1860776 & 1916873 & 1988364 & $100 \cdot 00$ \\
\hline
\end{tabular}

（注） ト・シリコクロムは眅売贯のみを示す，

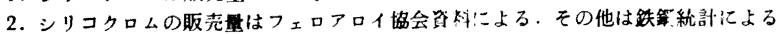

3. 酸化モリブデンおよびタングステン酸カルシウムは除外した。 


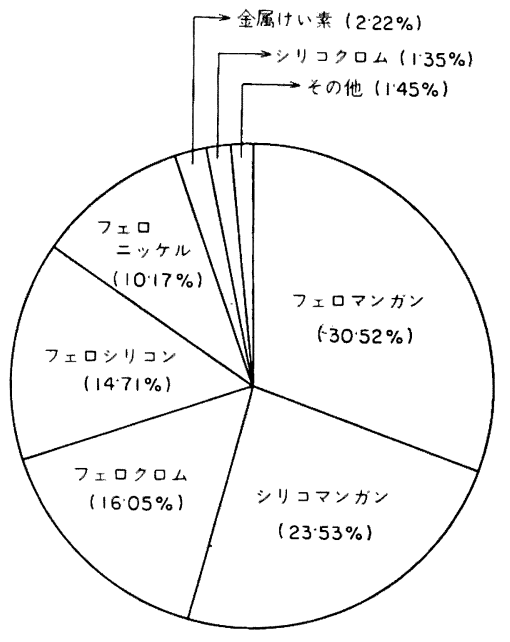

合計 1988000 トン

因 3 フェロフロイ品種別生産量(昭和 47 年)

(日本フェロフロイ協会資料)

\section{$2 \cdot 3$ 企業統合}

フェロアロイ工業合理化の基本方針にそつて体制の整 備を進めてきたが，とくに一般的品種であるフェロマン ガン系, フェロシリコンおよびフェロクロム系などにつ いて重点的に合理化，体制整備が進められた。昭和 39 年に業界全体で 49 社存在しており, そのうちフェロマ ンガン系製造メーカーは 20 社, フェロクロム系製造メ 一カーは 11 社あつたものが, 昭和 47 年にはそれぞれ 10 社および 5 社に整備統合されて減少した. しかし, フェロシリコン製造メーカーはカーバイト企業よりの転 入があり, 昭和 39年の 24 社に対して現在 16 社程度 にしか減つていないが，その内容には大きな変化が生じ ている. 昭和 47 年現在, 業界全体で 43 社であるが, 業界内では製造メーカーの1社多品種生座より少品種専 業化が促進された.

以上のようにして日本のフェロアロイ工業の 1 社当た りの年間平均生産高は海外主要国の規模に近づきつつあ る(表 2 ).

\section{4 設備の更新と生産能力の增大}

企業統合, 集中生産の方針にそつた結果, 電気炉 1 炉

表 2 海外主要国フェロフロイ1社当たり 年間平均生産高（1971 年）

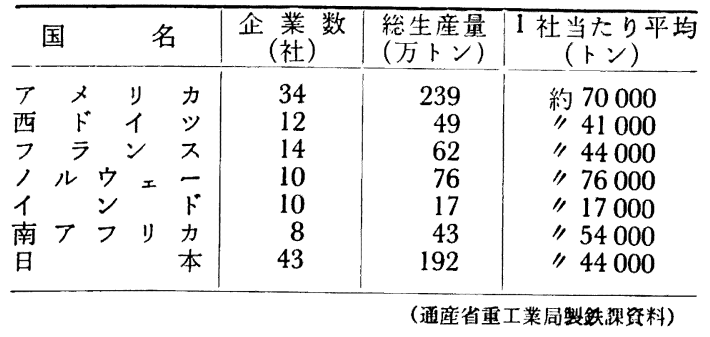

当たりの設借トランス平均容量は，図4 に示すように， 合理化計画以前の昭和 32 年から昭和 38 年にかけては 約2 000 5 000kVA であつたものが，昭和 41 年以降に は急激に增大し, 昭和 47 年には高炭素フェロマンガン $21000 \mathrm{kVA}$, フェロシリコン $15000 \mathrm{kVA}$ に見られるよ うに大容量化した。なお新設炉に関しては後述するよう に 40000〜60000 kVA というような大型炉が続々と建 設され，スクラップ・アンド・ビルト化が促進されてい る.

昭和 40 年代に入り日本全般にわたつて公害問題が起 こつてきたが，フェロアロイ工業ではいち早くこれに対 処すべく集じえ機の設置に努め, その結果昭和 44 年に はフェロマンガン, 高炭素フェロクロム, フェロシリコ ンの電気炉は 40〜50\% の設置率を示し, 以後昭和 46 年より急激に增加し昭和 48 年前半には全電気炉に設置 完了の予定である.

なお電気炉の作業環境の改善, 発生ガスの有効利用と 集じん機の設置に関連して, 特殊な条件の場合を除いて 電気炉の密閉化が進工, 新設備はほとんどが密閉炉とな つている.

トランス容量别の電気炉数の推移を図 5 に示すが，こ れによつて昭和 38 年に比べ昭和 42 年に炉数が激減し たことと，トランス容量が次第に大型化したことがわか る. 電気炉基数は昭和 38 年から昭和 42 年の間に約 20 $\%$ 減少し以後横ばいに近い状態になつている. 昭和 42 年から昭和 45 年の間に炉の大型化が急速に進み, さら

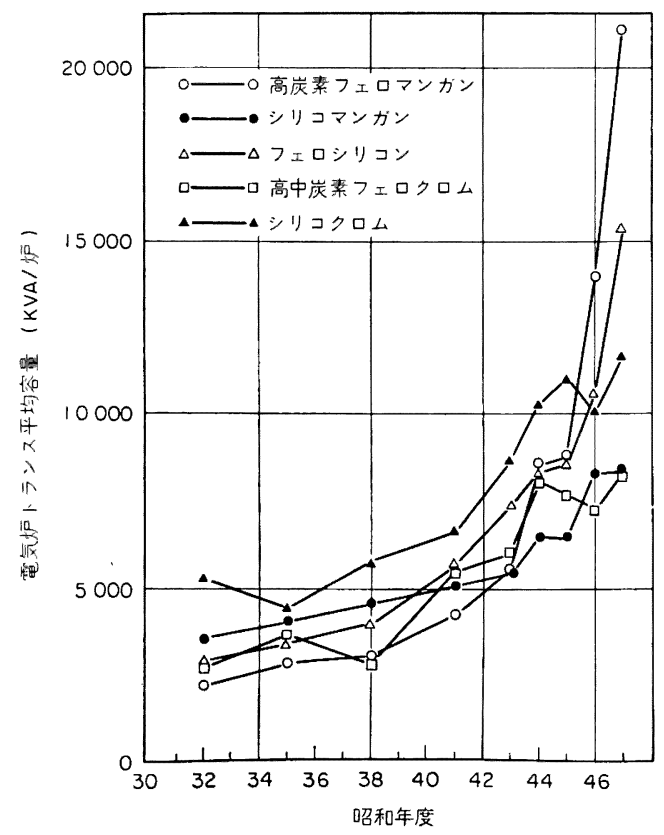

図4フェロフロイ生産主要電気炬トランス平均容 量の推移 （日本フェロアロイ協会資料） 


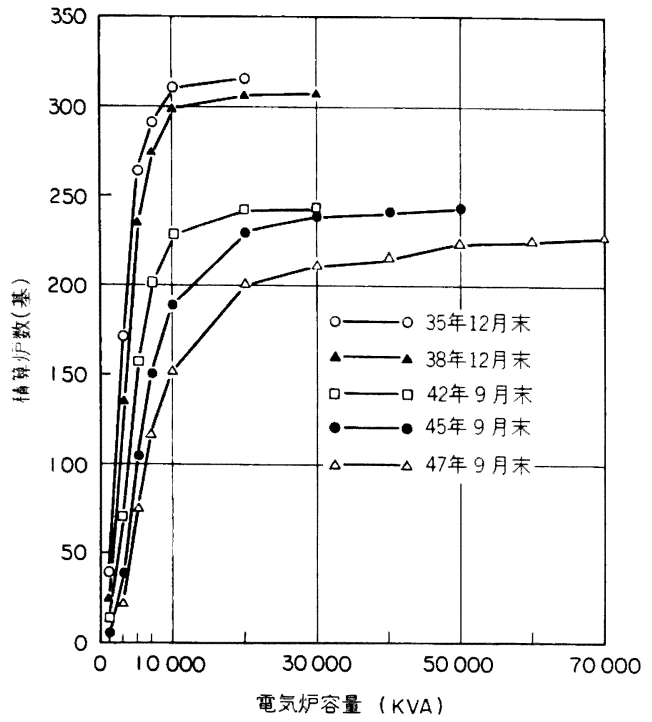

図 5 フェロ丁ロイ用容量別保有電気炉数推移 (フェロニッケルを除く)

（日本フェロ丁ロイ協会資料）

にその後飛躍的に大型化されたことがわかる.

昭和 47 年 9 月現在のフェロアロイ生産用電気炉設借 能力を表 3 に示す. 生産中止拉よびスクラップ化のもの を除き, 合計で電気炉数約 200 基, 約 $1500000 \mathrm{~kW}$,

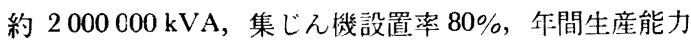
約 290 万トンである.

\section{3. 立地条件の変化と技術の発達}

\section{$3 \cdot 1$ 立地条件の变化}

フェロアロイ生産工場の分布を見ると裏日本の北陸地 方あるいは東北地方内陸地区に数多くの工場が散在して いる.これらの地方は, 元来豊富で廉価な余剩電力およ び余剩兴㑛力を利用できるという有利な条件から選ばれ たものであるが，歴史的に特色を有したこの工場立地 も, 今日に沶いては電力の火主水従, 労働力の逼迫, さ らには大量の原料を海外に依存するということなどのた めに，かえつて合理化推進の障害となつている. その上 フェロアロイ生産量の伸びに伴つて, 必然的に原料輸送 および製品の大口需要家への輸送量の増加が問題にな り, 立地条件をほかに求踇海工業地帯に進出する結果 となつた，すなわち，岡山県水島地区へ水島合金鉄，茨 城県鹿岛地区人中央電気工業, 徳島県阿南市人日本電 工，兵庫県加古川市入神户製鋼所，北九州市洞岡地区人 日本重化学工業が進出し, 総合的設備を持つ大型密閉炉 が相次いで建設された. また, 臨海工業地帯の鉄鋼メ一 カーへ直結し, 製品の溶湯を直接供給する例としては山 口県新南陽市周南地区の周南電工がある.

\section{$3 \cdot 2$ 製造技術の発達}

\section{$3 \cdot 2 \cdot 1$ 大型炉の設置状況}

新鋭大型炉は昭和 42 年以降統々と郜海工業地带また は各メ一カーの主要工場内に建設されることになつた が，その先駆となつたものはすでに昭和 $29 ， 32$ 年に建 設された日本鋼管の $4000 ， 5000 \mathrm{kVA}$ 完全密閉型フェ ロマンガン炉2) で，排ガス利用を目的とするものであつ

表 3 フェロフロイ生産電気炉設備能力 昭和 47 年 9 月

\begin{tabular}{|c|c|c|c|c|c|c|c|c|c|c|c|}
\hline \multirow[b]{2}{*}{ 品 } & \multirow{2}{*}{$\begin{array}{l}\text { 電気 } \\
\text { 如数 } \\
\text { (基) }\end{array}$} & \multirow{2}{*}{$\begin{array}{l}\text { 電 気 炉 } \\
(\mathrm{KW})\end{array}$} & \multirow{2}{*}{$\begin{array}{l}\text { トランス } \\
\text { 容 } \\
(\mathrm{KVA})\end{array}$} & \multicolumn{2}{|r|}{ 炉 } & の & \multicolumn{2}{|l|}{ 式 } & \multicolumn{2}{|c|}{ 集じえ機 } & \multirow{2}{*}{$\begin{array}{l}\text { 年間生産 } \\
\text { 能 } \\
(\text { カン) }\end{array}$} \\
\hline & & & & 固定 & 回転 & 開放 & 密閉 & $\begin{array}{l}\text { 半密 } \\
\text { 閉 }\end{array}$ & $\begin{array}{l}\text { 基数 } \\
\text { (台) }\end{array}$ & $\%$ & \\
\hline フェロ $\begin{array}{c}\text { 高 炭 素 } \\
\text { 中ンカ低炭素 } \\
\text { 計 }\end{array}$ & $\begin{array}{l}12 \\
17 \\
29\end{array}$ & $\begin{array}{r}175900 \\
24520 \\
200420\end{array}$ & $\begin{array}{r}252500 \\
43810 \\
296310\end{array}$ & $\begin{array}{l}10 \\
10 \\
20\end{array}$ & $\begin{array}{l}2 \\
7 \\
9\end{array}$ & $\begin{array}{r}2 \\
13 \\
15\end{array}$ & $\begin{array}{r}10 \\
4 \\
14\end{array}$ & $\begin{array}{l}- \\
-\end{array}$ & $\begin{array}{l}12 \\
11 \\
23\end{array}$ & $\begin{array}{r}100 \\
65 \\
79\end{array}$ & $\begin{array}{l}650000 \\
200000 \\
850000\end{array}$ \\
\hline 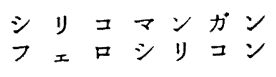 & $\begin{array}{l}40 \\
43\end{array}$ & $\begin{array}{l}316850 \\
483260\end{array}$ & $\begin{array}{l}334650 \\
658300\end{array}$ & $\begin{array}{l}29 \\
28\end{array}$ & $\begin{array}{l}11 \\
15\end{array}$ & $\begin{array}{l}30 \\
40\end{array}$ & $\begin{array}{r}10 \\
3\end{array}$ & - & $\begin{array}{l}33 \\
39\end{array}$ & $\begin{array}{l}83 \\
91\end{array}$ & $\begin{array}{l}640000 \\
448000\end{array}$ \\
\hline フェロ $\begin{array}{c}\text { 高炭素中 } \\
\text { クロ }\end{array}$ & $\begin{array}{l}38 \\
13 \\
51\end{array}$ & $\begin{array}{r}228310 \\
48600 \\
276910\end{array}$ & $\begin{array}{r}316625 \\
67800 \\
384425\end{array}$ & $\begin{array}{r}32 \\
9 \\
41\end{array}$ & $\begin{array}{r}6 \\
4 \\
10\end{array}$ & $\begin{array}{r}35 \\
7 \\
42\end{array}$ & $\frac{3}{3}$ & $\begin{array}{r}- \\
6 \\
6\end{array}$ & $\begin{array}{r}30 \\
6 \\
36\end{array}$ & $\begin{array}{l}79 \\
46 \\
71\end{array}$ & $\begin{array}{l}610,000 \\
170000 \\
780000\end{array}$ \\
\hline $\begin{array}{l}\text { シリコクロ } \\
\text { カルシウムシリュン } \\
\text { フェロタングステン } \\
\text { 高炭素 } \\
\text { フェロリブデン } \\
\text { 金属けい素 }\end{array}$ & $\begin{array}{r}10 \\
7 \\
2 \\
4 \\
11\end{array}$ & $\begin{array}{r}83600 \\
23750 \\
1400 \\
2200 \\
82350\end{array}$ & $\begin{array}{r}116600 \\
37950 \\
3015 \\
3300 \\
122950\end{array}$ & $\begin{array}{r}6 \\
6 \\
- \\
4 \\
4\end{array}$ & $\begin{array}{r}4 \\
1 \\
2 \\
- \\
7\end{array}$ & $\begin{array}{r}9 \\
7 \\
-\end{array}$ & $\frac{1}{-}$ & $\overline{-}$ & $\begin{array}{l}8 \\
5 \\
2 \\
3\end{array}$ & $\begin{array}{r}80 \\
71 \\
100 \\
75 \\
82\end{array}$ & $\begin{array}{r}100000 \\
14520 \\
1700 \\
1500 \\
50000\end{array}$ \\
\hline 合 & 197 & 1470740 & 1957500 & 138 & 59 & 156 & 33 & 8 & 158 & 80 & 2885720 \\
\hline
\end{tabular}

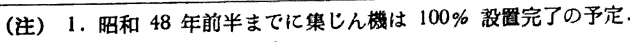

2.フェロニッケルを除く.

3. 集しん機 1 基を 2 姖以上で共用する掦合は，その炬数を樂しん機基数として算定した． 
た. その後昭和 36 年に日本重化学工業の $12000 \mathrm{kVA}$ 半密閉型シリコンマンガン炉3) および昭和 37 年に日本 鋼管の $20000 \mathrm{kVA}$ 半密閉型フェロクロム炉4)などが設 置された.これらは単に当時としては大型の密閉炉であ つたばかりでなく，集じん機が倩えられており，とくに 後者は原料の前処理, 捕集ガスの有効利用, 製品. スラ グ処理設䟮をも僃えたものとして注目された，その間炤 和 38 年より竦村金属工業では通産省の研究補助金を得 て，原料予熱方式による高炭素フェロマンガン製鋉法5) の研究を行なつたが，その成果と「フェロアロイ工業合 理化対策」のモデルプラントの立案に従つて, 昭和 40 年岡山県水島地区に川崎製鉄, 㯨村金属工業, 揖斐川電 工, 昭和鉄合金, 信越化学工業の共同投資による水島合 金鉄に $7800 \mathrm{kVA}$ 密閉型フェロマンガン炉が建設され6)， 続いて $19000 \mathrm{kVA}^{7)}, 40000 \mathrm{kV}$ 密閉炉が建設された. これらは始めて臨海工業地带に建設された総合的なプラ ントとなつたのである. これが刺激となり以後続々と新 鋭大型炉が建設されることになつたが, 表 4 に最近の主 要大型電気炉を示す. 最大トランス容量はフェロマンガ

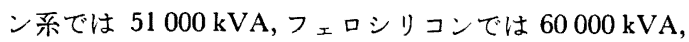
フェロクロム系で $40000 \mathrm{kVA}$, フェロニッケルでは $40000 \mathrm{kVA}$ である.

\section{$3 \cdot 2 \cdot 2$ 大型炉による操業技術}

これらの大型電気炉によるフェロアロイの製造方式に ついて述べる.フェロマンガン系に関しては, 電気炻の 大型化にともない密閉化が進行した.原料, 製品の整粒は 普通に行なわれている. 原料の前処理方法としては，1) 密閉炉中で，燃焼または未燃炶のままの発生ガスにより 原料の予熱などを行ない，あわせて集じんも行なわせ， 最終の排出ガスは湿式集じん機で処理する水島合金鉄,

2) 粉鉱石を焼結する一連の製造方法の日本電工3）8）お よび神戸製鋼所")，３）ロータリーキルンによる予備還

表 4 フェロフロイ生産主要大型電気炉

\begin{tabular}{|c|c|c|c|c|}
\hline 品 & $\begin{array}{l}\text { 設置 } \\
\text { 年 }\end{array}$ & 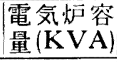 & 型式 & 会 社 名 \\
\hline 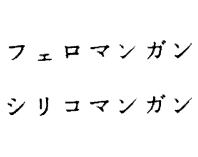 & $\begin{array}{l}46 \\
46 \\
46 \\
45 \\
45\end{array}$ & $\begin{array}{l}51000 \\
40500 \\
40000 \\
40000 \\
40000\end{array}$ & $\begin{array}{l}\text { 密閉 } \\
\text { 密閉 } \\
\text { 密閉 } \\
\text { 密閉 } \\
\text { 密閉 }\end{array}$ & $\begin{array}{l}\text { 日本重化学工業 } \\
\text { 日本電 管 } \\
\text { 日本鋼 管 } \\
\text { 中央電 気工業水島 合金鉄 }\end{array}$ \\
\hline フェロシリコ & $\begin{array}{l}46 \\
45 \\
43 \\
45 \\
44\end{array}$ & $\begin{array}{l}60000 \\
45000 \\
45000 \\
40000 \\
36000\end{array}$ & $\begin{array}{l}\text { 密閉 } \\
\text { 開放 } \\
\text { 密閉 } \\
\text { 開放 } \\
\text { 開放 }\end{array}$ & 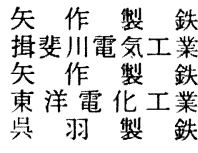 \\
\hline $\begin{array}{l}\text { フェロクロム } \\
\text { シリコクロム }\end{array}$ & $\begin{array}{l}45 \\
47 \\
46 \\
45 \\
37\end{array}$ & $\begin{array}{l}40000 \\
25000 \\
23000 \\
20000 \\
20000\end{array}$ & $\mid \begin{array}{c}\text { 密閉 } \\
\text { 開放 } \\
\text { 密閉 } \\
\text { 密閉 } \\
\text { 半密閆 }\end{array}$ & 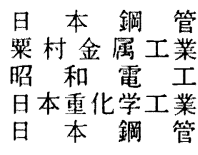 \\
\hline フェロニッケル & 45 & 40000 & 密閉 & 太平洋金属 \\
\hline
\end{tabular}

元鉱石をホットチャージする中央電気工業の方法などが 一般に知られている.

フェロシリコンに関しては，開放炉がおもであるが,

1）鉱石法で製造する矢作製鉄，2）75\% フェロシリコ ンを $15000 \mathrm{kVA}$ の密閉型電気炉で製造し排ガスを湿式 集じえ処理する上越電炉工業(10)などは世界的に優れた技 術水準といえる.

フェロクロム系に関しては，密閉炉がほとんどである が，この中で高炭素フェロクロムの幣造については，昭 和電工の $23000 \mathrm{kVA}$ および周南電工の $18000 \mathrm{kVA} の$ 密閉型電気炉は炭材を配合した子薉還元ペレットのホッ トチャーシ法を採用しており，その電力原単位は 2000 $\mathrm{kWh} / \mathrm{t}$ 程度1112) といわれている. 低炭素フェロクロム の製造に関してはペラン法が日本において改良され良好 な結果を得ている.

\section{$3 \cdot 2 \cdot 3$ 製造電力原単位}

粗製品トン当たりの使用電力量を図 6 に示す.

フェロシリコンについては昭和 30 年に約 $11600 \mathrm{kWh}$ /t であつたのが，昭和 44 年には $9400 \mathrm{kWh} / \mathrm{t}$ まで低 下し, 昭和 45 年と昭和 46 年にはやや上つて約 9900 $\mathrm{kWh} / \mathrm{t}$ 程度となつている. 昭和 30 年当時に比べて 約 15\% 低減したことになる。

高炭素フェロマンガン, シリコマンガン, 高炭素フェ ロクロムおよび低炭素フェロクロムはほぼ直線的に隇少 しており, 昭和 30 年と昭和 46 年の電力原単位の比較 および減少率は次のようである.

昭和 30 年 昭和 46 年 減少率 高炭素フェ 䄪 $3700 \mathrm{kWh} / \mathrm{t}$ 約 $2400 \mathrm{kWh} / \mathrm{t}$ 約 $35 \%$ ロマンガン

シリコマン 約 6200 ”約 4000 ” 約 35 ”

高炭素フェ 約 6200 " 約 3500 " 約 44 " ロクロム

低炭素フェ 約 4800 ”約 2200 ”約 54 ” ロク口ム

\section{4. 日本フェロアロイ協会の活動}

日本のフェロアロイ工業は, 日本フェロアロイ協会を 場として各種の共同活動を行なつているが，それらのう ち技術的活動のおもなものについて以下に述べる.

\section{1 技術委員会}

フェロアロイ技術委員会は戦前昭和 16 年 11 月に設 置されたが，戦後昭和 21 年 5 月に再開され，業界の技 術向上に奇与してきた. 現在までに 180 回ほど開催さ れている.

特記事項としては次のようである.

(1) フェロアロイ工業合理化対策に参画

前述のとおり, 合理化対策の計画は昭和 39 年 1

月に企てられたが，その中で「生産設備および技術 の改善」,「フェロアロイモデルプラント」に関して分担 


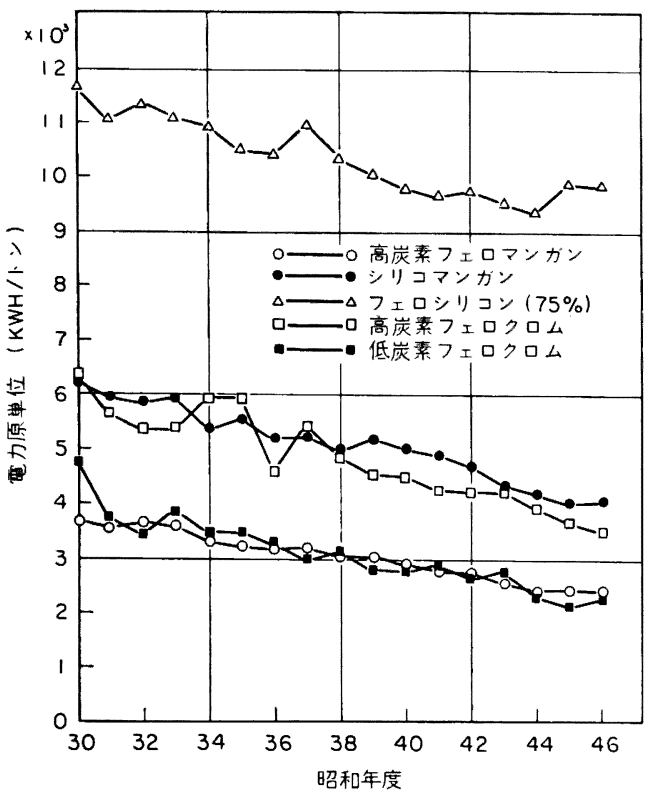

図 6 主要製品電力原単位

（日本フェロアロイ協会資料）

した.

（2）技術講習会の開催

毎年 2 回講習会を催しており，これらは「フェ口 アロイ」誌に発表されている.

（3）フェロアロイの JIS 制定化に協力

技術委員会の活動の大きなものの一つとして当初 より活発に行なつてきていたが, JIS 制定後も 3 年 おきに原料，製品規格，サンプリングおよび分析な どについて見直しを行なつている.

（4）その他

各種調査, 研究などが行なわれているが, これら については「フェロアロイ」誌に詳細に記載されて いる.

\section{2 環境管理委員会}

技術委員会の下部組織として, 昭和 41 年 6 月公害対 策委員会が発足した。これは公害対策基本法制定の前年 であつて，業界としてはいち早くその活動を始めた．そ の内容としては，まず電気炉などの排出ばい煙の調査を 行ない，業界の実態把握につとめた. その結果, 今日で はほとんどすべての設備について集じえ機の設置を見る にいたつている. 日本フェロアロイ協会としては, 各企 業が，公害防止のあらゆる可能性を追求し，果敢に投資 を試み, 公害防止に積極的に取り組む姿をとることが企 業が社会・民衆に支持され, 企業が生き延びる道にほか ならないと基本的に考えている。このようにして, さら に昭和 46 年 12 月公害対策委員会を環境管理委員会に 改組, 強化した. 以後, 上記の技術的調査・研究の継続
のほかに，公寒関係諸法規に関する理解の徹底を図ると ともに, 関係当局との相互理解を深め情報交换を行な い，環境管理・改善につとめている。また 1970 年 9 月 に当時各社が実施あるいは計画していた公害防止対策の 実情を欧米各国と比較検討し，かつ政府，地方自治体と 民間諸機関の協力状況を調査するために欧米五力国を視 察した ${ }^{13)}$ ．その結果，世界においても日本の水準は相当 高いことが判明した．このように日本フェロアロイ工業 の公害防止対策は世界一流の水準に達していると考光ら れる.

\section{3 国際標準化機構への参画}

1947 年 6 月チューリッヒで国際標準化機構 (ISO) が発足したが, 日本つェロアロイ協会も 1972 年からP メンバーとしてフェロアロイ尃門委員会 TC-126に参 加し, モスコー会合に出席した. 分科会の活動として は SC-1 ではサンプリング，SC-2 では分析，SC-3 で は製品規格について検討しており，日本としてはJIS 規 格を提出しているが，1973 年 5 月には西ドィッで開催 が予定されている.

そのほか，マンガン鉱石尃門委員会 TC-6514) では 1967 年 5 月モスコーの会合に日本フェロアロイ協会か らも代表が出席した。棟は 1967 年から P メンバーと なり日本フェロアロイ協会がサンプリング尃門委員会の 分科会を設置し本部事務局と連絡をとつている.

\section{5. 公 害 対 策}

\section{$5 \cdot 1$ 概況}

日本フェロアロイ協会環境管理委員会の活動について は先に述べたが，業界における公害対策の現状は概略つ ぎのとおりである.

生産設備の主体が電気炉およびその付带設備であるの で, 公害防止対策の対象はばいじん, 粉じん, 騒音がお もでそれ以外には湿式集じん機排水の水質污濁である.

最も困難なのはばいじんであつて，原料の粉じんおよ び成品のフュームを含む高温でかつ発生量の変化が激し い電気炉排ガスである.この排出基準は当初は $900 \mathrm{mg} /$ $\mathrm{Nm}^{3}$ であつたため簡単なサイクロンなどでほぼ目的を 達していたが，昭和 45 年 12 月のいわ河る公害国会で 特別排出基準が $200 \mathrm{mg} / \mathrm{Nm}^{3} \quad(\mathrm{Si}>40 \%$ の品種には $400 \mathrm{mg} / \mathrm{Nm}^{3}$ ) と強化され, かつ地方自治体からはほと んど肉眼で見え收程度にまで減少させるように要望され るにいたり，ここに完全な集じん機を備えた新鋭大型炉 が出現し一方老朽小型炉は次第にスクラップ化されてい る.

\section{$5 \cdot 2$ 設備状況}

フェロアロイ生産用電気炉集じん機の設置は昭和 48 年前半にすべて完了するが*，表 3 および表 5 に示すよ うに昭和 47 年 9 月現在の状況では, 高炭素フェロマン

* 昭和 48 年 6 月に完了した。(追䍇) 
表 5 フェロフロイ生産主要電気炉付属集じん装置種類 昭和 47 年 9 月

\begin{tabular}{|c|c|c|c|c|c|c|c|}
\hline 品種 & $\mid \begin{array}{|cc|}\text { ば } & \text { 煙 } \\
\text { 捕収方法 }\end{array}$ & $\begin{array}{r}\text { シンチュリー| } \\
\text { スクラパー| }\end{array}$ & \begin{tabular}{|l|}
$\mid$ タイゼン \\
ウォッシュワー|
\end{tabular} & サイクロン類| & $\begin{array}{l}\text { パッグ } \\
\text { フィルター| }\end{array}$ & 計 & 備 \\
\hline $\begin{array}{l}\text { 高炭素 } \\
\text { フェロマンガン }\end{array}$ & $\begin{array}{ll}\text { 密 } & \text { 閉 } \\
\text { 開 } & \text { 放 }\end{array}$ & 5 & 4 & 1 & 2 & $\begin{array}{r}10 \\
2\end{array}$ & 全炉完 \\
\hline シリュマンガン & $\begin{array}{ll}\text { 密 } & \text { 閉 } \\
\text { 開 放 }\end{array}$ & 4 & 6 & 3 & 20 & $\begin{array}{l}10 \\
23\end{array}$ & $\begin{array}{l}\text { 未設置 } 7 \text { 炉は } \\
47.12 \text { 完 }\end{array}$ \\
\hline フェロシリコン & $\begin{array}{ll}\text { 密 } & \text { 閉 } \\
\text { 開 } & \text { 放 }\end{array}$ & 3 & & & 36 & $\begin{array}{r}3 \\
36\end{array}$ & $\begin{array}{l}\text { 未設置 } 4 \text { 炉中 } 2 \text { 灯は } \\
\text { 静電式の予定 }\end{array}$ \\
\hline $\begin{array}{l}\text { 高中炭素 } \\
\text { フェロロム }\end{array}$ & $\begin{array}{ll}\text { 密 } & \text { 閉 } \\
\text { 開 } & \text { 放 }\end{array}$ & $\begin{array}{l}2^{*} \\
4\end{array}$ & 1 & 4 & $\begin{array}{l}(2) \\
19\end{array}$ & $\begin{array}{r}3 \\
27\end{array}$ & $\begin{array}{l}\text { 未設置 } 8 \text { 炬中 } 2 \text { 炉 } \\
47.12,6 \text { 炉 } 48.5 \text { 完 }\end{array}$ \\
\hline シリ & $\begin{array}{ll}\text { 密 } & \text { 閉 } \\
\text { 開 放 }\end{array}$ & 1 & & 1 & 6 & $\begin{array}{l}1 \\
7\end{array}$ & $\begin{array}{l}\text { 未設置 } 2 \text { 叔 } 47.12 \\
\text { パッグフィルター完 }\end{array}$ \\
\hline 金属けい素 & $\begin{array}{ll}\text { 密 } & \text { 閉 } \\
\text { 開 } & \text { 放 }\end{array}$ & & & & 9 & 9 & \begin{tabular}{|l} 
未設置 2 炉 48.6 \\
トッッフィルター完 \\
\end{tabular} \\
\hline 計 & $\begin{array}{l}\text { 密 閉 } \\
\text { 開 放 }\end{array}$ & $\begin{array}{r}15 \\
4\end{array}$ & $\begin{array}{r}11 \\
0\end{array}$ & $\begin{array}{l}1 \\
8\end{array}$ & $\begin{array}{l}(2) \\
92\end{array}$ & $\begin{array}{r}27 \\
104\end{array}$ & \\
\hline
\end{tabular}

ガンは各品種中最も合理化が進み集じん対策も完了して いる.

密閉炉にはベンチュリースクラバーおよびタイゼンワ ッシャーが採用されており, 開放炉はいずれも小容量炉 で，これにはバッグフィルターが採用されている.シリ コマンガンについては高炭素フェロマンガンと同様であ る.フェロシリコンはほとんどが開放炉でバッグフィル ターを採用し, 密閉炉にはベンチュリースクラバーが採 用されており，未設炉には静電式とバッグフィルターが 設置されることになつている. 高炭素フェロクロムでは 密閉炉にはベンチュリースクラパー, タイゼンワッシャ 一が採用され，開放炉にはバッグフィルターがおもでべ ンチュリースクラバー，マルチクロンなども採用されて いる. シリコクロムでも密閉炬にはベンチュリースクラ バー，開放炉にはバッグフィルターがおもである.

金属シリコンは他品種にくらべてばいじん濃度が高 く，かつダスト粒径も小さいうえ，ガス温も高いことな どから集じん対策がおくれていたが，バッグフィルター が設置されることになつている. 全般的に見て, 密閉炉 にはベンチュリースクラバーまたはタイゼンワッシャー が主体で 96\% を占めており，開放炉にはバッグフィル ターが主体で 88\% を占めている. 集じん機排出ガス中 のばいじえ濃度は，前者で $100 \mathrm{mg} / \mathrm{Nm}^{3}$ 以下，後者は $10 \mathrm{mg} / \mathrm{Nm}^{3}$ 以下であつて，排出基準をはるかに下迴る 値となつている.

\section{6. 今後の 課 題}

日本のフェロアロイ工業の企業合理化対策を促進する ために企業統合および製造設備の合理化をはかつた結 果, 一貫した設備を持つ新鋭大型電気炉が臨海工業地帯
および各所に建設され，かつ公害防止に全力をあげて対 処してきて, ほぼその目的を達したものと考えられる.

今後の課題としては, まず第 1 に原料資源の問題であ る.フェロアロイ工業は一部の原料を除きほとんどすべ てを海外に仰いでいるが，その輸送に関しては輸送船の 大型化にともなつてその購入は比較的容易となつてい る.しかし原料を資源国よりの輸入にのみ依存している のが現状であつて，鉄鋼業あるいは非鉄金属鉱業のよう に自力で投資，技術開発した原料を持たないが，現在二， 三開発を計画中で，今後これを積極的に促進する必要が あると考える.

第 2 に日本のエネルギー問題である. 現在の日本にお けるエネルギーは海外より輸入されている原油あるいは 原子力八の依存度が高く，これを使用する各電力会社が 公害問題により発電所の開発が難航しており,さらに一 般の電力消費は GNP の上昇にともなつてきわめて急激 に伸びているので電力の不足は眼に見えている. したが つて電力多消費型産業であるフェロアロイ工業に対する 影響は相当大きく働くものとなろう.

第 3 に現在フェロアロイ業界およびフェロアロイ需要 業界が最も関心を有するのは, 日本フェロアロイ業界の 国際競争力の問題である. 四囲の状況は為替レートの変 化による輸入製品の価格低下，世界的好況に押し上げら れつつある原産地での原料価格および海上運賃の高騰に よるフェロアロイ原料の価格上昇, 前項の電力不足によ る電力単価の上昇, 日本国内の人件費の高騰および副原 料その他の直接費ならびに間接費の上昇など, 国内生産 フェロアロイの価格的競争力を压迫する要因が数多く押 しよせてきている. これらはもちろんフェロアロイの品 種によつてかなりの差異はあるが, 大なり小なり競争力 
を低下させることは明らかである.しかしながら一方， 需要業界における製造技術は日進月歩し, 使用するフェ ロアロイに対しての要求も時々刻々と変化している. こ れに対処しかつ不要の在庫を持つことなく, 最も有効に フェロアロイを使用できるということは, 国内フェロア ロイ業界によつてのみ実現しうることであり，かつこの ことは国内のフェロアロイ業界ならびにフェロアロイ需 要業界の双方にとつての利点であるはずである．この利 点を有意義ならしめるために両業界が密接に相協力し, 製造技術の改善向上, 管理部門の合理化などを推進し， 輸入フェロアロイに対する品質ならびに価格の国際競争 力を強化することこそ，わが国フェロアロイ業界にとつ て今後の最大の課題であると考える. したがつて，われ われ技術担当者の責任たるや誠に重大である.なお，需 要急増時に輸入品へ殺到するという愚はいたずらに原産 地価格の吊り上げをきたすものであるから，その必要あ る場合は品種および数量を検討して計画的に輸入すべき である.

$$
\text { 文献 }
$$

1)フェロフロイ工業合理化対策委員会：フェロフロ
イ工業合理化対策, 昭和 39 年 1 月

2) 下村，ほか：フェロ丁ロイ，14 (1965) 1, p. 20

3 ) 成瀨：鉄と鋼，53(1972) 8, p. 124

4 ) 岩淵: フェロアロイ, 16 (1967) 5, 6, p. 257

5 ) 三宅，ほか：フェロアロイ，15 (1966) 1, p. 28

6 ）那須，ほか：フェロフロイ, 15 (1966) 5, 6, p. 375

7 ) J. Nasu: Metal Bulleitn, Tues. Oct. 7 (1969), p. 21

8 ) W. Naruse: Metal Bulletin, Special Issue, (1971), p. 87

9) 坂口: フェロフロイ, 21 (1972) 2, p. 69

10) 堀部: フェロアロイ, 21 (1972) 2, p. 83

11）市川，ほか：日新製鋼技報，26，June，1972， p. 78

12) Y. Kanoh: Metal Bulletin, Special Issue, (1971), p.83

13）日本フェロアロイ協会編：公害関係海外調査団報 告, 1970. 9

14）日本フェロフロイ協会技術委員会：フェロフロ 1, 20 (1971) 2 